\title{
Sheep as a Biological Control Agent for Tansy Ragwort
}

\author{
STEVEN H. SHARROW AND WAYNE D. MOSHER
}

\begin{abstract}
Tansy ragwort (Senecio jacobaea) is a biennial weed commonly found on forest and pasture lands in the maritime regions of the Pacific Northwest. Pyrrolizidine alkaloids in tansy ragwort, when consumed by most types of livestock, produce progressive and irreversible liver damage. Sheep, however, appear immune to these alkaloids. To evaluate the possibility of using sheep to suppress tansy ragwort in cattle pastures, 100 plants were marked and their status followed during 1977 and 1978 in pastures grazed by cattle alone and in pastures grazed by both cattle and sheep. Total tansy ragwort mortality did not differ between pastures. However, the cause of mortality did differ. Mortality on the cattle-grazed pasture was predominately due to completion of the plant's biennial life cycle (blooming and seed set), while most plant mortality on the sheep plus cattle pasture appeared to be the result of grazing. The data suggest that sheep may be used as a biological control agent to suppress tansy ragwort populations by reducing their ability to produce seed.
\end{abstract}

Tansy ragwort (Senecio jacobaea) is a biennial or weak perennial weed which is widely distributed in the maritime climatic regions of northern California, western Oregon, and western Washington. It is estimated to occur on approximately three million acres of forest and rangelands in western Oregon alone (Isaacson and Schrumpf 1979). A recent survey of dryland pastures in western Oregon (Isaacson and Schrumpf 1979) indicated that $43 \%$ of these pastures are currently infested. The average level of infestation is high, being approximately 1800 flowering stems per hectare. Not surprisingly, the economic impact of this infestation is also high. Annual economic losses in western Oregon are estimated to be $\$ 600,000$ due to forage displacement alone (Isaacson and Schrumpf 1979). Perhaps more important, however, then reduced forage production a re potential losses of livestock which may be poisoned when they consume tansy ragwort. Tansy, like several other Senecio species, contains pyrrolizidine alkaloids (Kingsbury 1964), which when consumed are metabolized in the liver into active pyrrol derivatives, causing liver damage (Craig 1979). These alkaloids have been demonstrated to be toxic to monogastrics such as humans (Huxtable 1979) and rats (Shull et al. 1976), caecae digesters such as horses (Craig 1979), and to ruminants such as cattle (Craig 1979) and goats (King and Dickenson 1979). Cattle losses in Oregon attributed to tansy ragwort poisoning in 1971 alone were valued at $\$ 1.2$ million (Snyder 1972). This figure would undoubtedly be much higher if it were not for the relatively low palatability of tansy ragwort to most livestock. Sheep, on the other hand, readily consume it and seem immune to its toxic properties. It is not clear if sheep possess the ability to destroy pyrrolizidine alkaloids in the rumen (Dick et al. 1963) or if the alkaloids are not activated in the liver (Shull et al. 1976). In any event, there is little evidence to suggest that sheep are poisoned even when large amounts of tansy ragwort are consumed (Craig 1978).

\footnotetext{
Authors are assistant professor, Rangeland Resources Program, Oregon State University, Corvallis; and rancher, Roseburg, Ore., respectively.

This report was submitted as Tech. Pap. No. 5692. Oregon Agr. Exp. Sta., Corvallis.

-Manuscript received November 17, 1980.
}

Because of the widespread distribution of tansy ragwort together with public concern over the use of herbicides on both public and private lands, recent efforts to control this species have centered on biological control. Two insect agents, the flea beetle (Longitarus jacobaea), which feeds on roots and stems, and the cinnabar moth (Tyria jacobaea), whose caterpillars feed principally on leaves, have been introduced for this purpose. Unfortunately, they have not as yet proven successful in reducing tansy ragwort to acceptable levels on a large scale by themselves. The purpose of this paper is to discuss sheep as an additional biological control agent.

\section{Methods}

In order to investigate the effects of sheep grazing on individual tansy ragwort plants, a study was established on the Mont Alto Ranch near Glide, Oregon, in May 1977. The site chosen was a moist valley bottom associated with steep hillsides which once supported Douglas-fir (Pseudotsuga menziesii) forest. The entire area was grazed by cattle each spring. Two plots, one grazed by cattle, the other grazed by cattle in the spring followed by sheep in the early summer of 1977 , were sampled during 1977 and 1978 . On each plot, steel posts were driven into the ground $30 \mathrm{~m}$ apart. These posts then served as reference points to permanently locate the positions of 100 tansy ragwort plants on each plot. Plants were subsequently relocated and identified by triangulation from the posts on August 8, 1977, May 15, 1978, and December 20, 1978. On each sampling date, the number of leaves, number of flower clusters, and the general appearance of each plant were recorded. This information was used to place plants into seven status groups as follows: (1) vegetative-undefoliated rosettes, (2) reproductive plants with flowers present, (3) dry plants-dry, undefoliated rosettes, (4) stripped leaf petioles-rosettes from which all leaf tissue had been removed, (5) stripped flower stalks plants from which all leaves and flowers had been removed, (6) stubs--plants reduced to a leafless stub less than $3 \mathrm{~cm}$ long, and (7) not observed-no evidence of the plant was found.

Plant mortality was ascribed to one of three sources as follows: (1) bloomed-plants in status 2 or 5 on August 8, 1977, not observed alive in 1978, (2) grazing-plants in status 4 or 6 on August 8, 1977, not observed alive in 1978, and (3) unknownplants in status 1,3 , or 7 on August 8,1977 , not observed alive in 1978.

Statistical comparisons between the cattle-grazed and the sheep and cattle-grazed plots were made using $\chi^{2}$ contingency tables (Steel and Torrie 1960).

Forage utilization was accessed at the end of the grazing season in 1977 by a single a rea-wide ocular estimate for each plot on August 8, $19,77$.

In order to evaluate the nutritional value of tansy ragwort plants, ten flowering plants were collected on June 28, 1979. Plants were hand-separated into leaf, flower, and stem materials. Plant materials were oven dried $\left(50^{\circ} \mathrm{C}\right)$, ground in a Wiley mill ( $\# 60$ mesh screen) and like materials composited to form a single sample. Duplicate sub-samples of leaf, flower, and stem tissue were 
analyzed for protein content $(\mathrm{N} \times 6.25)$ by the micro Kjeldhal procedure (A.O.A.C. 1970). In vitro digestibility was determined for three subsamples of each plant part by the Tilly and Terry (1963) procedure.

\section{Results and Discussion}

Forage utilization on the cattle-grazed plot appeared to be light (about 20\%) in 1977, while total utilization on the cattle + sheep plot was quite high (about $80 \%$ ). Although no animal data were taken, the sheep seemed to gain weight despite the heavy utilization. This was not surprising, as tansy ragwort during the summer period is generally considered to be good feed for sheep. Chemical analysis of flowering tansy ragwort plants collected in early summer 1979 (Table 1) supported this contention. Leaves and

Table 1. Percent protein and in vitro digestibility of tansy ragwort plants collected June 28, 1979.

\begin{tabular}{lcc}
\hline \hline Plant part and requirement & \% Protein & \% Digestibility \\
\hline Leaves & 10.4 & 75 \\
Stems & 2.6 & 46 \\
Flowers & 14.5 & 71 \\
NRC (maintenance - ewes) & 8.9 & 55 \\
NRC (growing lambs)' & 11.0 & 67 \\
\hline
\end{tabular}

'Dietary nutrient requirements as listed by the National Research Council (1975).

flowers, the most readily consumed portions of the plants, exceeded NRC (1975) dietary requirements for ewes both in terms of crude protein and percent digestibility. It is interesting to note that both of these plant parts also met the digestibility requirements for growing lambs. In addition, the protein content of flowers was adequate for lambs while that of leaves was only slightly deficient. Stems, however, were quite fiberous and woody at this growth stage. Their low protein content and digestibility reflected this. The protein contribution made by a plant such as tansy ragwort to sheep diets may be especially important as utilization tends to occur during the summer months when other green feed is scarce.

The status of tansy ragwort plants on August 8, 1977, immediately after sheep were removed is shown in Table 2 . Sheep

Table 2. Number of tansy ragwort plants per status group on August 8, 1977.

\begin{tabular}{lccc}
\hline & \multicolumn{3}{c}{ Sheep+Cattle } \\
Group & Cattle-Grazed & Grazed & $\chi^{2}$ \\
\hline Vegetative & 15 & 0 & $* 1$ \\
Reproductive & 40 & 2 & $* 1$ \\
Dry plants & 2 & 0 & $\mathrm{NS}^{2}$ \\
Stripped leaf petioles & 7 & 0 & $* 1$ \\
Stripped flower stalks & 0 & 3 & $\mathrm{NS}^{2}$ \\
Stubs & 9 & 30 & $* 1$ \\
Not observed & 27 & 65 & $* 1$ \\
$\quad$ Total plants studied & 100 & 100 & \\
\hline
\end{tabular}

1*Cattle-grazed plot significantly different from sheep + cattle grazed plot, $P<.05$. $2^{\mathrm{NS}}$ No significant difference, $P>.05$.

appeared to be efficient defoliators of tansy ragwort. On the cattlegrazed plot, 43 plants were defoliated compared to 100 plants on the cattle + sheep grazed plot. The intense defoliation achieved by sheep grazing was effective in preventing tansy ragwort from flowering and producing seed as evidenced by only $2 \%$ of the plants flowering in 1977 on the sheep + cattle plot compared to $40 \%$ on the cattle-grazed plot. Furthermore, the two plants which were able to bloom on the sheep + cattle plot produced only one or two capitula each while blooming plants on the cattle-grazed plots produced dozens of capitula per plant.

A concern frequently expressed by producers and researchers alike is that tansy ragwort plants may be converted from a biennial to a weak perennial growth habit as a result of defoliation by livestock. The practical effect of such a shift in growth habit would be to allow individual plants to persist in a pasture until either a year of particularly favorable climatic conditions or a reduction in livestock grazing pressure allowed them to bloom and to mature seed. If this occurred, effective control of tansy ragwort could not be achieved through defoliation of the plants by livestock. Fortunately, this does not appear to be the case. Re-examination of the same tansy ragwort plants in 1978 (Table 3), a year in which cattle

Table 3. Number of tansy ragwort plants observed in each status group on August 8, 1977, subsequently observed alive in May or December 1978.

\begin{tabular}{lcc}
\hline \hline Group & Cattle-Grazed & $\begin{array}{c}\text { Sheep + Cattle } \\
\text { grazed }^{\text {I }}\end{array}$ \\
\hline Vegetative & $8 / 15(53 \%)$ & $0 / 0$ \\
Reproductive & $8 / 40(20 \%)$ & $0 / 2$ \\
Dry plants & $2 / 2(100 \%)$ & $0 / 0$ \\
Stripped leaf petioles & $7 / 7(100 \%)$ & $0 / 0$ \\
Stripped flower stalks & $0 / 0$ & $0 / 3$ \\
Stubs & $7 / 9(78 \%)$ & $19 / 30(63 \%)$ \\
Not observed & $10 / 27(37 \%)$ & $13 / 65(20 \%)$ \\
\hline
\end{tabular}

'August 1977/May and/or December, 1978

but no sheep grazing occurred, revealed that a considerable number of plants originally present in 1977 were not present in 1978. Of special interest were the reproductive plants on the cattlegrazed plot. While $80 \%$ of these plants died following flowering in 1977 , the remaining $20 \%$ were true perennials in that they remained alive following seed production. In fact, three of these plants not only grew vigorously the next year (1978), but also flowered for a second time. It this occurrence of perennality is shared by other tansy ragwort populations, their seed-producing ability may be much higher than is generally recognized.

While the total amount of mortality was similar on both cattle + sheep and cattle-grazed plots (Table 4), the cause of mortality was quite different. Mortality on the cattle-grazed plot was predomi-

Table 4. First year of mortality of tansy ragwort plants.

\begin{tabular}{lccc}
\hline & \multicolumn{3}{c}{ Type of Grazing } \\
\cline { 2 - 4 } Source of mortality & Cattle & Sheep + & $\chi^{2}$ \\
\hline Bloomed & 32 & 2 & $* 1$ \\
Grazing & 2 & 14 & $* 1$ \\
Unknown & 24 & 52 & $* 1$ \\
Total mortality & 58 & 68 & NS $^{2}$ \\
\hline
\end{tabular}

1*Cattle-grazed plot different from sheep + cattle plot, $P<.05$

${ }^{\mathrm{NS}}$ No significant difference, $P>.05$.

nately due to completion of the life cycle including both flowering and seed production. On the sheep + cattle plot, however, mortality was largely the result of grazing. This is more evident when one realizes that unless a stub or other grazed plant part was observed, mortality was attributed to "unknown causes." Many plants were so completely consumed by the sheep that the location of any plant remains was extremely difficult. Thus, much of the "unknown" mortality class was likely due to sheep grazing.

It appears, therefore, that intensive grazing by sheep can effectively reduce the ability of tansy ragwort plants to flower and produce seed. Reduced seed production, together with the death of established plants resulting from the intensive, frequent defoliation which occurs under close grazing, may allow reduction of tansy ragwort populations to acceptable levels. Furthermore, tansy ragwort appears to be a relatively high quality feed for sheep, providing protein to their diet in the summer when other herbage is dry. 


\section{Literature Cited}

A.O.A.C. 1970. Official methods of analysis (11th edition). Ass. Off. Agr. Chem., Washington, D.C. 1147 p.

Craig, M. 1978. Tansy and sheep. p. 20-22. In: Sheep and Wool Days. Oregon Agr. Exp. Sta. Spec. Rep. 506.

Craig, M. 1979. Serum enzyme tests for pyrrolizidine alkaloid toxicosis in cattle and horses. p. 135-144. In: Symposium on pyrrolizidine (Senecio) alkaloids: toxicity, metabolism, and poisonous plant control measures. Nut. Res. Inst., Oregon State Univ., Corvallis.

Dick, A.T., A.T. Dann, and L.B. Bull. 1963. Vitamin $B_{12}$ and the detoxification of hepatotoxic pyrrolizidine alkaloids in rumen liquor. Nature 197:207-208.

Huxtable, R.J. 1979. Herbal teas and pyrrolizidine alkaloids. p. 87-94. In: Symposium on pyrrolizidine (Senecio) alkaloids: toxicity, metabolism, poisonous plant control measures. Nut. Res. Inst., Oregon State Univ., Corvallis.

Isaacson, D.L., and B.J. Schrumpf. 1979. Distribution of tansy ragwort in western Oregon. p. 163-169. In: Symposium on pyrrolizidine (Senecio) alkaloids: toxicity, metabolism, and poisonous plant control measures.
Nut. Res. Inst., Oregon State Univ., Corvallis.

King, R.R., and J.O. Dickinson. 1979. Comparative aspects of pyrrolizidine alkaloid toxicity in cattle and goats. p. 69-76. In: Symposium on pyrrolizidine (Senecio) alkaloids: toxicity, metabolism, and poisonous plant control measures. Nut. Res. Inst., Oregon State Univ., Corvallis. Kingsbury, J.M. 1964. Poisonous Plants of the United States and Canada. Prentice-Hall Inc., Englewood Cliffs, N.J.

National Research Council. 1975. Nutrient requirements of sheep. Nat. Acad. Sci., Washington, D.C.

Shull, L.R., G.W. Buckmaster, and P.R. Cheeke. 1976. Factors influencing pyrrolizidine (Senecio) alkaloid metabolism: species, liver sulfhydryls and rumen fermentation. J. Anim. Sci. 43:1247-1 253.

Snyder, S.P. 1972. Livestock losses due to tansy ragwort poisoning. Oregon Agr. Rec. No. 255.

Steel, R.G.D., and J.H. Torrie. 1960. Principles and Procedures of Statistics. McGraw-Hill Book company, Inc., New York.

Tilley, J.M.A. and R.A. Terry. 1963. A two-stage technique for in vitro digestion of forage crops. J. Br. Grassland Soc. 18:104-111.

\section{Special Management Needs of Alpine Ecosystems}

edited by Douglas A. Johnson

This publication presents six papers given at a special symposium presented at the annual meeting of the Society for Range Management in Casper, Wyoming, in February, 1979. Titles include:
Alpine Ecosystems of Western North America
Physiological Responses of Plants in Tundra Grazing Systems
Range Management in the Alpine Zone
Hydrologic Aspects Related to the Management of Alpine Areas
Revegetation of Disturbed Alpine Rangelands
Future Management and Research Needs in Alpine Ecosystems

Extensive bibliographical material extends the value of the papers, which present current information about the mysterious world of the alpine tundra. Increased demands for food and fuel have created greater pressure on these fragile lands, and so current information about them would be of value to those responsible for their use and reclamation, environmentalists, research students, and individuals interested in an unusual and fascinating ecosystem. Soft-bound $\bullet 120$ pages $\bullet \$ 4.50$ postpaid. 